\title{
EDITORIAL
}

\section{In This Issue: Community Health, Clinical Care, and Clinician Calling}

\author{
Kurt C. Stange, $M D, P b D$, Editor \\ Ann Fam Med 2018;16:2-3. https://doi.org/10.1370/afm.2187.
}

$\mathrm{T}$ his issue of Annals of Family Medicine provides diverse perspectives on community health, clinical care, and clinicians' calling as healers.

A perspective by Ziegelstein highlights the increasing importance of knowing the patient as a person in an era in which precision medicine sometimes coopts the larger meaning of personalized care. ${ }^{1}$

In a study of a large nationally representative sample, Sites et al find that opioid prescription for musculoskeletal problems is associated with patient satisfaction. A dose-response effect and biological and social plausibility argue that the association may be causal. These findings give credence to current efforts to reform public and patient expectations about opioid prescribing. ${ }^{2}$

Community health workers have shown value in many settings, but have not commonly been incorporated into patient-centered medical homes. In a large qualitative study, Rogers and colleagues identify both facilitators and barriers to adopting community health workers in this setting. ${ }^{3}$

The combination of family practice and hot spotting (targeting geographic areas of high disease prevalence) is an appealing strategy for amplifying screening efforts. Heil et al apply this strategy to a birth cohort to screen for Hepatitis B and C. The strategy yields a high rate of uptake but identifies no hidden chronic infections, reminding us of the importance of a (high) baseline prevalence of disease for screening to be effective. ${ }^{4}$

South Africa's district health system provides an interesting milieu for examining health system performance and clinical processes influenced by family physicians. Von Pressentin et al find mixed associations with the presence of family physicians, depending on the setting-better health care system performance and clinical processes in district hospitals, and poorer in community health centers. ${ }^{5}$ These findings call to mind the work of Geoff Meads, who found that primary care manifests very differently in diverse sociopolitical environments. ${ }^{6-9}$ Understanding context is important in understanding and enhancing the effects of family medicine and primary care. ${ }^{10-15}$
An in-depth video-recording study provides interesting insights into how health care professionals-including general practitioners, nurses, and dieticians-communicate with people with newly diagnosed diabetes. Despite displaying generally high levels of technical knowledge and general communication skill, consultations often are driven by biomedical explanations that are out of context from patient experience. In spite of a perception of time pressure, much time is spent repeating information that may not be relevant to patients' needs. The findings imply that framing communication more squarely on patients' needs and receptivity could increase both the effectiveness and efficiency of communication with people with a new diagnosis of diabetes. ${ }^{16}$

Clinicians frequently experience requests for treatment or advice from family or friends. In a qualitative study, Giroldi and colleagues provide insights into the nuanced factors considered by junior and senior physicians in dealing with these requests. ${ }^{17}$

A research brief by Aslan et al provides the dirt on a little-known hyperpigmented skin lesion called terra-firma-forme-dermatosis. ${ }^{18}$

Board certification may be a marker for better training, higher quality, and greater system connectedness. In a national study, Liaw et al find that being male, an international medical graduate, or older at initial certification is associated with family physicians not recertifying. ${ }^{19}$

A special report by Weiss et al brings to light important considerations for engaging medical interpreter services in outpatient care. ${ }^{20}$

Social complexity risk factors for high emergency department use by Medicaid-insured children are found to be identifiable through state administrative data in a cohort study of more than a half million children by Arthur et al. ${ }^{21}$

In a study of 4th-year medical students, Kao and colleagues find that identifying with medicine as a calling is associated with higher odds of selecting a primary care-related residency. ${ }^{22}$

An essay by Loxterkamp calls for junior family physicians to express their genuine desire to help others 
by considering the long arc of their careers, and to find meaning and purpose in touching the lives of those they serve. ${ }^{23}$

Another essay reflects on dramatic events initiated by a physician's denial and fortune in surviving a near death experience of a heart attack. ${ }^{24}$

This issue's Innovation in Primary Care includes an interdisciplinary behaviorally focused model for medication-assisted treatment of opioid use disorder. ${ }^{25}$

We welcome you to join the online discussion for each of the articles at http://www.AnnFamMed.org.

\section{References}

1. Ziegelstein RC. Perspectives in primary care: knowing the patient as a person in the precision medicine era. Ann Fam Med. 2018;16(1):4-5.

2. Sites BD, Harrison J, Herrick MD, Masaracchia MM, Beach ML, Davis MA. Prescription opioid use and satisfaction among pain patients. Ann Fam Med. 2018;16(1):6-13.

3. Rogers EA, Manser ST, Cleary J, Joseph AM, Harwood EM, Call KT. Integrating community health workers into medical homes. Ann Fam Med. 2018;16(1):14-20.

4. Heil J, Hoebe CJPA, Cals JWL, ter Waarbeek HLG, van Loo IHM, Dukers-Muijrers NHTM. Detecting hepatitis B and C by combined public health and primary care birth cohort testing. Ann Fam Med. 2018;16(1):21-27.

5. von Pressentin KB, Mash RJ, Baldwin-Ragaven L, Botha RPG, Govender I, Steinberg WJ, Esterhuizen TM. The influence of family physicians in the South African district health system. Ann Fam Med. 2018;16(1):28-36.

6. Meads G. Primary Care in the Twenty-First Century. Seattle, WA: Radcliffe; 2006.

7. Meads G. PCTs as laboratories of change- notes from small countries. Prim Care Rep. 2003;5(9).

8. Meads G. Lessons from South Africa's struggle. Prim Care Rep. 2004;6(19):16-19.

9. Meads G, Iwami M, Wild A. International Primary Care Developments. The Transferable Learning. Coventry: University of Warwick. Centre for Primary Health Care Studies; 2004.

10. Stange KC. Practical and contextual issues. Ann Fam Med. 2005;3(6):556-557.
11. Stange KC. On TRACK: In and out of context. Ann Fam Med. 2006;4(1):81-82.

12. Stange KC. In this issue: practice change-context matters. Ann Fam Med. 2013;11(3):198-199.

13. Stange KC, Glasgow RE. Contextual Factors: The Importance of Considering and Reporting on Context in Research on the PatientCentered Medical Home. June, 2013. AHRQ Publication No. 13-0045EF: http://pcmh.ahrq.gov/page/contextual-factors-importanceconsidering-and-reporting-context-research-patient-centered.

14. Tomoaia-Cotisel A, Scammon DL, Waitzman NJ, et al. Context matters: the experience of 14 research teams in systematically reporting contextual factors important for practice change. Ann Fam Med. 2013;11(Suppl 1):S115-S123.

15. Balasubramanian BA, Heurtin-Roberts $S$, et al. Factors related to implementation and reach of a pragmatic multisite trial: the My Own Health Report (MOHR) study. J Am Board Fam Med. 2017;30(3):337-349.

16. Dowell A, Stubbe M, Macdonald L, et al. A longitudinal study of interactions between health professionals and people with newly diagnosed diabetes. Ann Fam Med. 2018;16(1):37-44.

17. Giroldi E, Freeth R, Hanssen M, Muris JWM, Kay M, Cals JWL. Family physicians managing medical requests from family and friends. Ann Fam Med. 2018;16(1):45-51.

18. Aslan NÇ, Güler \$, Demirci K, Isiyel E. Features of terra firma-forme dermatosis. Ann Fam Med. 2018;16(1):52-54.

19. Liaw W, Wingrove $P$, Petterson $S$, et al. Predictors of attrition from family medicine board certification. Ann Fam Med. 2018;16(1):55-58

20. Jacobs B, Ryan AM, Henrichs KS, Weiss BD. Medical interpreters in outpatient practice. Ann Fam Med. 2018;16(1):70-76.

21. Arthur KC, Lucenko BA, Sharkova IV, Xing J, Mangione-Smith R. Using state administrative data to identify social complexity risk factors for children. Ann Fam Med. 2018;16(1):62-69.

22. Kao AC, Jager AJ. Medical students' views of medicine as a calling and selection of a primary care-related residency. Ann Fam Med. 2018;16(1):59-61.

23. Loxterkamp D. Where we belong: an open letter to my colleagues in training. Ann Fam Med. 2018;16(1):80-82.

24. Stausmire JM, Greenbaum MG, Morelli-Greenbaum M. The day I died. Ann Fam Med. 2018;16(1):77-79.

25. Cantone RE, Fleishman J, Garvey B, Gideonse N. Interdisciplinary management of opioid use disorder in primary care. Ann Fam Med. 2018;16(1):83. 